\title{
Prevalence of lameness and associated risk factors on dairy farms in the Maritime Provinces of Canada
}

\author{
M. T. Jewell, ${ }^{1 *}$ M. Cameron, ${ }^{1}$ J. Spears, ${ }^{2}$ S. L. McKenna, ${ }^{1}$ M. S. Cockram, ${ }^{1}$ J. Sanchez, ${ }^{1}$ and G. P. Keefe ${ }^{1}$ \\ ${ }^{1}$ Department of Health Management, Atlantic Veterinary College, University of Prince Edward Island, Charlottetown, Prince Edward Island, \\ Canada, C1A 4P3 \\ ${ }^{2}$ Department of Biomedical Sciences, Atlantic Veterinary College, University of Prince Edward Island, Charlottetown, Prince Edward Island, \\ Canada, C1A 4P3
}

\section{ABSTRACT}

Lameness in dairy cattle is a major issue for the industry due to the effects on the welfare of the animal, the economic impact, and consumer perception. The aim of this study was to determine the prevalence of lameness and explore potential risk factors in the Maritime Provinces of Canada. Cows were scored for lameness and potential risk factors and were assessed in 46 freestall herds and 33 tiestall herds in Nova Scotia, New Brunswick, and Prince Edward Island. In freestall herds, lameness was assessed using the most common method, locomotion scoring. A cow with a gait score of $\geq 3$ out of 5 was considered to be lame. In tiestall herds, lameness was assessed using an alternative method known as stall lameness scoring. This assessment consisted of observation of the cow for 4 behavioral changes: standing on the edge of the stall, shifting weight, resting a limb, and uneven weight bearing when moved side to side. A cow displaying 2 or more of these behaviors was considered to be lame. At the time of the assessment, other animal-, environmental-, and management-based measurements were collected. These measurements were used in multivariable logistic regression analysis to determine risk factors that were associated with lameness for both freestalls and tiestalls independently. The prevalence of lameness was $21 \%$ for freestall-housed cattle and $15 \%$ for tiestall-housed cattle. Of the 1,488 tiestall-housed cows that were assessed, $68 \%$ showed no behavioral changes, whereas $15,15,2$, and $<1 \%$ showed $1,2,3$, or 4 changes, respectively. In freestalls, higher odds of lameness were seen when cows spent $\geq 3 \mathrm{~h} / \mathrm{d}$ in the holding area for milking compared with those that spent $<3 \mathrm{~h} / \mathrm{d}$. In tiestall herds, higher odds of lameness were seen when bedding material was wet compared with when it was dry. For both lactating cow facil-

Received July 9, 2018.

Accepted December 6, 2018.

*Corresponding author: mtjewell@upei.ca ity types, housing the dry cows and heifers on a deep bedded pack compared with tiestalls or freestalls was associated with a decreased odds of lameness. There were also many cow-level variables associated with lameness, including parity, daily milk production, stage of production, body condition, and width at the tuber coxae (hook bones). If producers become aware of the risk factors associated with lameness, they can make informed decisions on where to implement changes to help reduce the level of lameness in their herd.

Key words: lameness, freestall, tiestall

\section{INTRODUCTION}

A common animal-based measurement in dairy welfare assessments is lameness (Whay et al., 2003). This painful condition is commonly seen in commercial dairy herds and in North American studies has been reported to affect 15 to $55 \%$ of lactating dairy cows (von Keyserlingk et al., 2012; Westin et al., 2016). The prevalence of lameness can vary depending on the region, facility type and milking system, and criteria used to determine whether a cow is lame. For example, when assessing cattle using stall lameness scoring (SLS), the prevalence of lameness in the same population of cows could range from 6 to $74 \%$ depending on the number of observed behavioral changes used to classify a cow as lame (Gibbons et al., 2014). Wide variability in the prevalence of lameness is also seen at the herd level; for example, the reported herd-level prevalence in Canadian freestalls ranged from 0 to $69 \%$ (Solano et al., 2015). Lameness is not only an important welfare concern but also has a large financial impact on the dairy industry. One reason for this is decreased milk production. In a recent Canadian study, King et al. (2017) found that compared with sound cows, lame cows in automated milking system (AMS) herds produced $1.6 \mathrm{~kg} / \mathrm{d}$ less milk. Other reasons for financial loss include reduced reproductive performance (Garbarino et al., 2004; Bicalho et al., 2007) and an increased culling risk (Bicalho et al., 2007; Cramer et al., 2009). When considering all 
of these factors, it has been estimated that lameness costs on average US $\$ 175$ per case (Cha et al., 2010). To improve the welfare of dairy cattle and the financial outcomes for producers, the number of clinically lame cows needs to be reduced. It is important to know what risk factors are associated with lameness because some of these risk factors may have a direct or indirect causal role, and this may provide producers with information on when and how to intervene to decrease the prevalence of lameness in the dairy industry.

Numerous cow- and herd-level risk factors have been reported to be associated with lameness in dairy cattle. A higher risk of lameness has been found for older cows (Vanegas et al., 2006; Randall et al., 2015; Solano et al., 2015), those later in lactation (Onyiro et al., 2008; Solano et al., 2015), and underconditioned cows (Randall et al., 2015; Solano et al., 2015). A decreased risk of lameness has been found in herds that have deepbedded sand stalls (Chapinal et al., 2013; Solano et al., 2015; Cook et al., 2016) and rubber flooring throughout the pen (Vanegas et al., 2006). The behavioral time budget of a cow also plays a role in the risk of lameness. When a cow spends more time standing idle, whether it be in a stall (Cook et al., 2004) or in the holding area (Espejo and Endres, 2007), there is a higher likelihood that she will become lame.

A few recently published studies have focused on the prevalence and risk factors of lameness in commercial Canadian dairy herds; however, these studies did not include the 3 Maritime Provinces (Nova Scotia, New Brunswick, and Prince Edward Island) and focused primarily on freestall facilities. Currently, little is known about the prevalence of lameness in this region of Canada and about risk factors associated with lameness in tiestall facilities. Therefore, the objectives of this study were (1) to estimate the prevalence of lameness in the Maritime Provinces of Canada in both freestall and tiestall facilities and (2) to explore relationships between lameness and various animal-, environmental-, and management-based risk factors measured on these herds.

\section{MATERIALS AND METHODS}

\section{Herd Selection}

A total of 80 dairy herds, both tiestalls and freestalls, from across Nova Scotia, New Brunswick, and Prince Edward Island chose voluntarily to participate in this study. The inclusion criteria for participation in the study were enrollment in the regional milk recording system provided by Valacta Inc. (Sainte-Anne-de-Bellevue, QC, Canada) and a milking herd consisting of primarily Holstein cows $(>80 \%)$. Recruitment of herds for the study occurred through regional veterinarians, advertisements in provincial dairy board newsletters, and cow comfort seminars by Valacta Inc. The primary author (MJ) then contacted each producer by phone to ensure that they met the inclusion criteria and confirmed their participation in the study.

\section{Cow Selection}

The number of cows assessed from each herd or management group within a herd (freestall facilities) was determined based on a sample size calculation for proportions. This calculation was based on the herd or group size, an estimated prevalence of $10 \%$, a precision of $5 \%$, and an accuracy of $95 \%$. Management groups or pens of lactating cows in freestalls were assessed independently if they were not in contact with each other or had major differences in design. Factors that were considered to be major differences were flooring type, stall base, feed barrier type, and bedding. When this occurred, the required number of animals to assess was determined based on each individual group size. When management groups were separated only by a gate and were designed similarly, the groups were treated as one. The number of animals required was calculated based on the total size of the groups, and animals were selected proportionately from each of the pens within this overall grouping.

In tiestalls, cows were selected for the assessment using a systematic random sampling scheme. However, in freestall herds, a random sampling scheme was not as easily achievable because the assessment was completed while the cows were freely moving around. To compensate for this, the observers took care to select animals from different areas of the pen and animals performing different behaviors, such as lying, feeding, walking, and drinking, and not just those in the proximity of the observers. Animals were selected as the observers walked through the herd until the required number of animals had been assessed. Due to the large proportion of the herd being sampled (67-90\%), multiple trips around the entire pen were required to achieve this. Cows were uniquely identified to ensure that they were not scored multiple times throughout the process. When locking head gates were present at the feed bunk or the assessment had to be completed during milking, cows were selected using a systematic random sampling scheme similar to that used in the tiestall facilities.

\section{On-Farm Assessments}

During each herd visit numerous animal-, environmental-, and management-based factors were measured. These visits were completed between September 2015 
and July 2016, and measurements were collected by 2 trained observers, one of which was always MJ and the other a student or technical assistant from the Atlantic Veterinary College (Charlottetown, PE, Canada). Observers were trained following previously described methods (Gibbons et al., 2012; Vasseur et al., 2013) and were required to achieve an interobserver agreement level of a weighted Cohen's kappa $>0.6$ before completing assessments on-farm. This level of agreement was achieved and maintained. Tiestall herds that were allowed access to pasture were assessed in the late spring (at the end of their winter housing period) to ensure that the observations reflected the housing environment as accurately as possible. All methods used to collect the data were approved by the Animal Care Committee at the University of Prince Edward Island (Charlottetown, PE, Canada; protocol no. 15-015).

\section{Animal-Based Measurements}

The cows selected to be in the study were assessed for the outcome of interest, lameness, by the primary observer (MJ) using live scoring. The type of lameness assessment performed differed between the 2 facility types. In freestall herds, lameness was assessed using locomotion scoring with a numerical ranking, as previously described (Flower and Weary, 2006; Solano et al., 2015), where cows with a score of $\geq 3$ out of 5 were considered lame. The gait of the cow was observed when the animal was walking at a normal pace and traveling in a straight path throughout the pen.

In tiestall herds, cows were evaluated using SLS as previously described (Leach et al., 2009; Gibbons et al., 2014; Palacio et al., 2017). With this method, the animals were evaluated in their stall for 4 behavioral changes: standing on the edge of the stall, resting 1 hind limb, shifting weight between hind limbs, and uneven weight bearing when moving side to side. The cows were required to stand for at least $3 \mathrm{~min}$ (Leach et al., 2009; Gibbons et al., 2014) before beginning the assessment. Following the protocol of Gibbons et al. (2014), the cow was observed undisturbed from behind for $30 \mathrm{~s}$ and evaluated from different angles for behavioral changes. Then the cow was encouraged to step side to side, 2 to 4 times, to assess weight bearing in the hind limbs. The cow was observed after movement for another $30 \mathrm{~s}$ for behavioral changes. A cow with 2 or more behavioral changes was considered to be lame.

Other animal-based measurements assessed on-farm were BCS, cleanliness, width and height of the cow. The BCS of the cow was assessed using the scoring chart described by Vasseur et al. (2013). Cows were scored on a scale of 1 (emaciated) to 5 (obese) with increasing increments of 0.25 . The cleanliness of the leg,
Table 1. Description of scoring system used to assess cleanliness of the leg, flank, and udder based on Vasseur et al. (2015)

\begin{tabular}{ll}
\hline Score & Description \\
\hline Clean & \\
0 & Fresh manure splashes on $<50 \%{ }^{1}$ of area \\
1 & Fresh manure splashes on $\geq 50 \%$ of area \\
Dirty & Dried manure on $\geq 50 \%$ of area \\
2 & Dried manure on entire area \\
3 &
\end{tabular}

${ }^{1} 50 \%$ of the area for the flank region was equivalent to standard lettersized paper for 1 single area of contamination.

flank, and udder was scored on a 4-point scale based on the amount and freshness of fecal contamination present, as shown in Table 1 and described previously (Solano et al., 2015; Vasseur et al., 2015). The area of the leg that was assessed was between the coronary band and lower half of the tarsal joint on the lateral aspect of the right limb. The flank region was defined as the area between the upper half of the tarsal joint and the level of the hooks and pins. Again, this was assessed on the right side of the animal. Given that the accumulation of contamination is primarily though manure splashed on the lower limb while walking, it is reasonable that there would be a balanced distribution for lower leg cleanliness. Cows appear to have no preference for which side they lie down on (Forsberg et al., 2008). Therefore, it would be expected that the manure contamination would be equally distributed on the right and left sides. For consistency between cows and to reduce the amount of time spent on animalbased measurements, evaluation of the right side only was chosen. In tiestalls, each animal was measured for the width between the tuber coxae (hook bones) and their height at the level of the rump (Nash et al., 2016).

\section{Environmental- and Management-Based Measurements}

During the assessment of the herd, quantitative and qualitative measurements were taken from the environment, including stall dimensions, bedding quality and quantity, and stocking density. The stall dimensions were measured on the stalls at either end of each row and averaged to determine the herd's stall size (Zaffino Heyerhoff et al., 2014; Solano et al., 2015). The stall dimensions included 9 stall aspects (e.g., stall width and rear curb height) in freestalls and 4 stall aspects (e.g., tie rail height and manger wall height) in tiestalls. Cows in tiestalls had designated stalls; therefore, the stall width and length of each individual cow was determined (Nash et al., 2016). The bedding quantity and quality were measured on the 2 middle stalls of each row. The quantity of bedding was determined by 
visual assessment of the entire stall. For organic bedding materials (straw, shavings), the presence of $>2$ $\mathrm{cm}$ of bedding was considered deep and $\leq 2 \mathrm{~cm}$ was considered sparse. When stalls were bedded with nonorganic materials (sand), the quantity of bedding was determined by the level of the rear curb, with presence at or above this level considered deep and below this level considered sparse (Zaffino Heyerhoff et al., 2014; Solano et al., 2015; Nash et al., 2016). At the herd level, the overall depth of bedding, regardless of the type, was considered deep if $>50 \%$ of the measured stalls were deep bedded. The quality of the bedding was then assessed on these same 2 stalls in each row. This was done by measuring the dryness of the bedding from 2 areas of each stall. A piece of paper towel folded into 4 was placed under the knee of the observer, who applied pressure to the bedding for $3 \mathrm{~s}$. The quality of the bedding was determined as dry or wet based on the number of layers and size of area on the paper towel that absorbed moisture, with the highest score being assigned to each stall (Vasseur et al., 2015). The stocking density was calculated as the number of cows in the herd or group divided by the number of useable stalls.

A questionnaire, adapted from the one developed and used by Vasseur et al. (2015), was administered by interview to each producer or farm manager. A total of 54 and 61 questions for tiestalls (Supplemental File S1; https://doi.org/10.3168/jds.2018-15349) and freestalls (Supplemental File S2; https://doi.org/10 .3168/jds.2018-15349), respectively, were asked during this interview. Multiple-choice and open-ended questions captured information about the management that may not have been measurable during the visit, such as frequency of hoof trimming, length of time needed to complete milking, and type of facilities the dry cows and heifers were reared in. The questionnaire also contained ranking questions that captured the thoughts and opinions of the producers on what causes lameness in cattle along with what factors prevent them from treating lameness promptly, such as lack of time, expense of treatment, and ease of getting a hoof trimmer.

\section{Statistical Analysis}

All data were analyzed using Stata14 (StataCorp, College Station, TX). The experimental unit was the cow, with the outcome of interest being whether the cow was classified as lame according to the scoring scheme. The prevalence of lameness in both facility types was determined at the cow and herd levels. The prevalence and $95 \%$ confidence interval at the cow level were determined from the inverse logit of a null model to account for the clustering effect within farms. Descriptive statistics (mean, standard deviation, minimum, and maximum) were used to review the characteristics of the outcome variable as well as cow- and herd-level explanatory variables presented in the causal diagram in Figure 1. Any intervening variables identified in the causal diagram were not included in the model building process. Using a random effect logistic regression model with herd as the random effect, the unconditional associations of the explanatory variables and the outcome were tested for each facility type. Continuous variables were assessed for linearity graphically on a logit scale and by fractional polynomials (Dohoo et al., 2009). If the relationship was determined to be nonlinear, the variable was categorized based on quartiles or industry recommendations and then tested for associations with the outcome. Variables that were unconditionally associated $(P \leq 0.2)$ with the outcome were carried forward to a multivariable logistic regression model. Before beginning the multivariable analysis, the explanatory variables were assessed for collinearity. If variables were highly correlated $(\mathrm{r}>0.7)$, the variable that had the strongest statistical association was considered for multivariable analysis.

Through a manual backward stepwise process, the final multivariable mixed-effects models were generated. This method started with all variables of interest in the model and continued by elimination of the most nonsignificant $(P>0.05)$ variable one at a time, with addition of previously removed variables. If the removal of a variable (1) resulted in a $>30 \%$ change in the coefficient of a remaining variable, (2) preceded and was associated with the outcome, and (3) was not an intervening variable in the causal diagram, the variable was considered to be a confounder and was left in the model. Once the final variables were decided, biologically plausible interactions between them were tested and kept in the model if significant $(P \leq 0.05)$. The fit of the model was assessed by checking the herd-level residuals for normality, both visually and statistically with a Shapiro-Wilk test. If outliers were identified, the effect of this herd on the model was determined by removing them from the analysis. If there was a significant difference in the results, they would be considered for permanent removal.

The results in this study are presented as clusterspecific estimates. These estimates are appropriate for making comparisons of 2 animals within the same herd for cow-level factors, such as DIM and BCS. Because herd-level factors are unlikely to vary within the same herd, we wanted to make comparisons between 2 cows from 2 different herds. To make this comparison accurately, it was more appropriate to use population-averaged estimates. To accomplish this, the variance components were calculated using latent variables and cluster-specific estimates were converted to population- 


\section{Stall Characteristics}

- Dimensions

- Stall Base

- Bedding Type/Depth

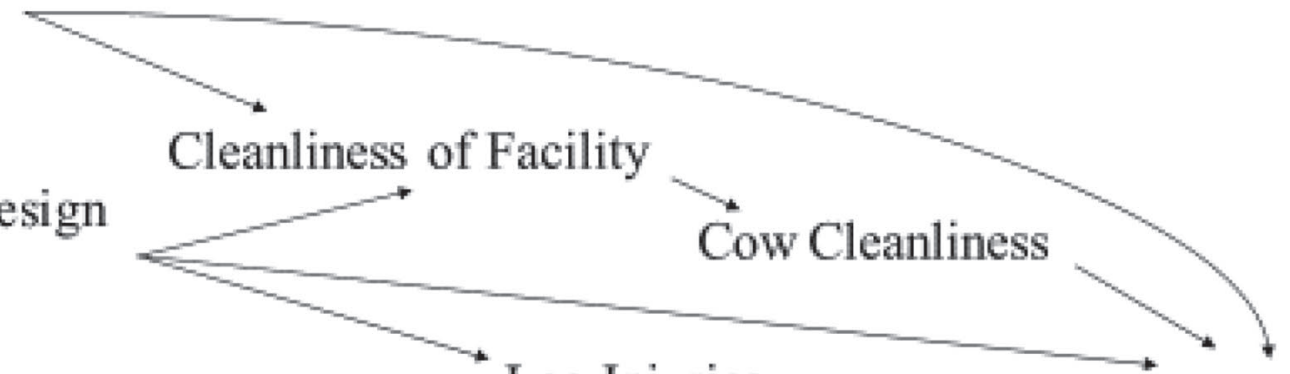

Pen Management/Design

- Stocking Density

- Flooring Type

Cow Characteristics

- Parity

- DIM

- Size

- Production Level

Feed Management

- Ration Type

- Feeding Frequency/Push Up

Other Management Factors

- Pasture Access

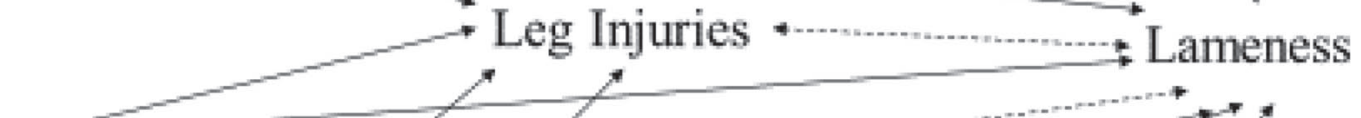

* Housing of Diy Cows/Heifers

Figure 1. Causal diagram depicting the potential relationships between animal-, environmental-, and management-based measurements and lameness in dairy cattle.

averaged estimates, when deemed appropriate, using the following equation: $\beta_{\mathrm{k}} / \sqrt{ }\left(1+0.346 \times \sigma_{\text {herd }}^{2}\right)$, where $\beta_{\mathrm{k}}$ is the regression coefficient from predictor $\mathrm{k}$ from the random effects model (i.e., cluster specific) and $\sigma_{\text {herd }}^{2}$ is the herd-level variance (Dohoo et al., 2009). The hierarchical structure of the data, as well as which factors are considered herd-level and cow-level predictors, is depicted in Figures 2 and 3.

\section{RESULTS}

\section{Description of Study Population}

A total of 80 commercial dairy herds were assessed, of which $34(43 \%)$ and $46(57 \%)$ were tiestalls and freestalls, respectively. These herds were distributed throughout the Maritime Provinces, with 18 in New Brunswick, 32 in Nova Scotia, and 30 in Prince Edward Island. Due to major differences in housing design, we decided to exclude 1 tiestall herd from the analysis; this herd was the only one housing lactating cows in stanchions. Similarly, 2 freestall herds were excluded from the analysis because of differences in housing design and management; one herd was the only barn with concrete stalls, and the other was the only herd not providing bedding material. Another 4 herds were excluded from the analysis due to inconsistencies in the availability of their production records (Supplemental Tables S1-S6; https://doi.org/10.3168/jds.2018-15349).

The 33 tiestall herds that were included in the analysis had a median (interquartile range) herd size of 60 (46-82) cows and ranged in size from 26 to 148 lactating cows. The average (standard deviation) production of these herds was $9,538(993) \mathrm{kg} /$ cow per year. Of the 1,347 cows in this group with production records, the average daily individual production was $33.6(9.32) \mathrm{kg}$ based on the test date data closest to the visit date. This group of cows was on average 186 (114) DIM. Of the 1,498 cows in this group that were measured for width between hook bones, the average width was $63.9(4.7) \mathrm{cm}$. An explanatory variable of interest was where the dry cows and heifers were housed before calving. Thirteen tiestall herds (39\%) housed the cows in a pack-bedded housing facility or straw yard. The other 20 herds (61\%) had either tiestall or freestall housing for dry cows and heifers. The remaining herd- and cowlevel explanatory variables in this study are described in Tables 2 and 3, respectively, along with the results from the univariable analysis for tiestalls. 


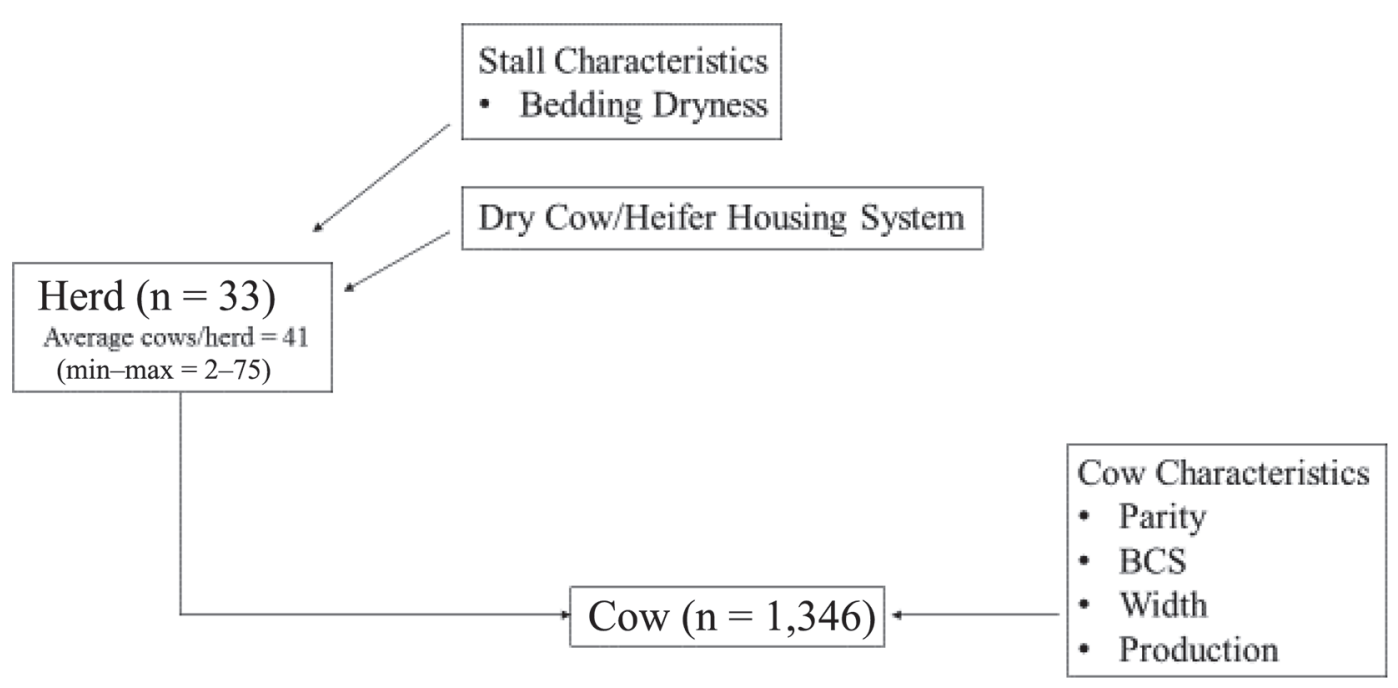

Figure 2. Hierarchical structure diagram illustrating the levels within the mixed-effect models for tiestall facilities as well as the risk factors associated with these levels. $\min =$ minimum; $\max =$ maximum.

The 40 freestalls included in the analysis had a median (interquartile range) herd size of 90 (50-121) cows and ranged in size from 22 to 255 lactating cows. These herds were producing on average $10,112(1,214) \mathrm{kg} / \mathrm{cow}$ per year. Of the 2,719 cows in this group with production records from the test date closest to the visit, average daily individual production was 33.7 (10) $\mathrm{kg}$. These animals were on average 182 (116) DIM. The measurement of the stall dimensions in these herds showed that the average height of the brisket board was 9.8 (7.1) $\mathrm{cm}$. Three main types of stall bases were used in these herds, with the most common being mattresses (58\%). Soil-based stalls, which were defined as a base of either sand or clay, were the next most common (30\%) type of stall base, and the least common were rubber mats $(12 \%)$. The distribution of the other herd- and cowlevel variables of interest in this study can be found in Tables 4 and 5, respectively, along with the results from the univariable analysis for freestalls.

\section{Prevalence of Lameness}

The prevalence of hind limb lameness for tiestallhoused cows was $15.3 \%$ (95\% CI: 12.5-18.6). The prevalence of lameness at the herd level for tiestalls ranged from 0 to $30.6 \%$ (Supplemental Figure S1; https:

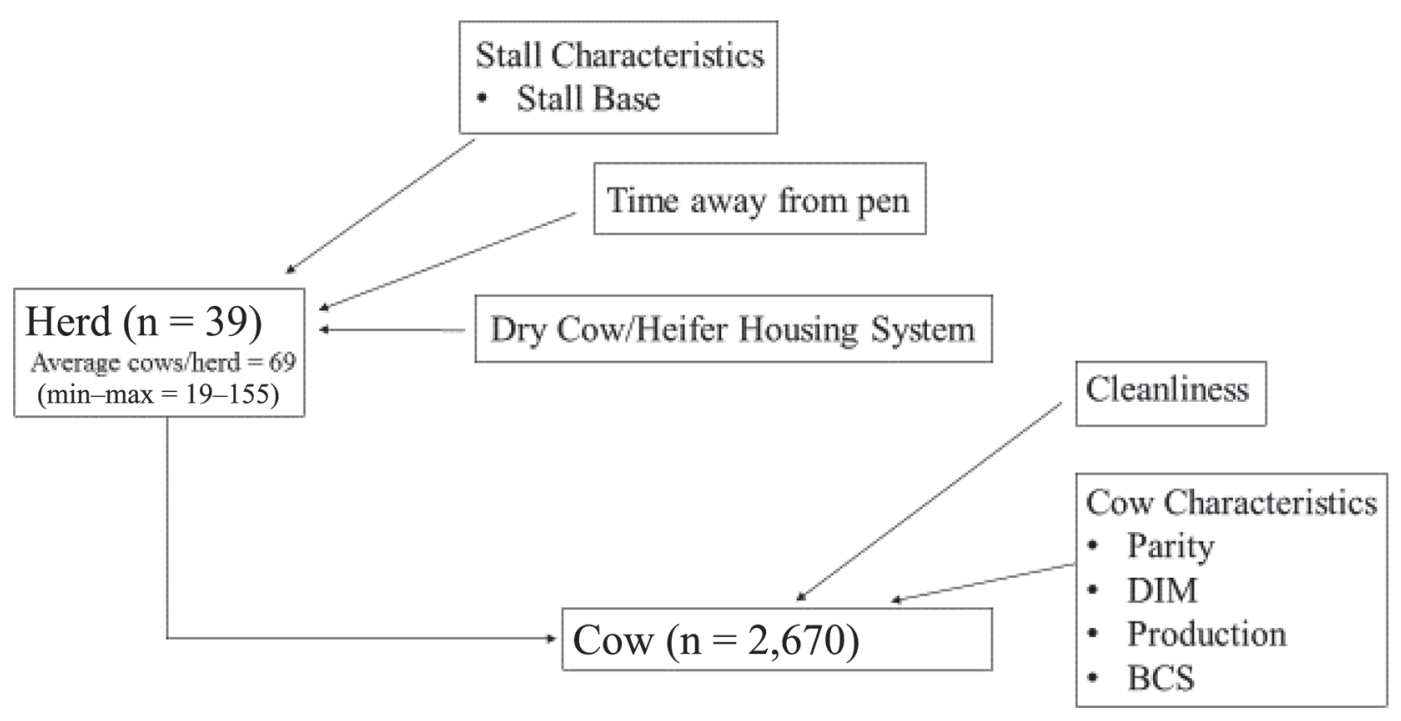

Figure 3. Hierarchical structure diagram illustrating the levels within the mixed-effect models for freestall facilities as well as the risk factors associated with these levels. $\min =$ minimum; $\max =$ maximum . 
Table 2. Distribution of herd-level variables that were unconditionally associated $(P \leq 0.2)$ with lameness after univariable analysis from 33 tiestall herds in the Maritime Provinces of Canada

\begin{tabular}{|c|c|c|c|}
\hline Variable & Category & Herds, no. ${ }^{1}(\%)$ & $P$-value \\
\hline \multirow[t]{3}{*}{ Bedding type } & Straw/hay & $19(58)$ & 0.006 \\
\hline & Wood by-product & $7(21)$ & \\
\hline & Combination & $7(21)$ & \\
\hline \multirow[t]{2}{*}{ Bedding depth } & Sparse/none & $7(21)$ & 0.128 \\
\hline & Deep & $26(79)$ & \\
\hline \multirow[t]{2}{*}{ Maximum bedding wetness } & Dry & $9(27)$ & 0.146 \\
\hline & Wet & $24(73)$ & \\
\hline \multirow[t]{2}{*}{ Dry cow housing } & Pack bedded & $13(39)$ & 0.022 \\
\hline & Other & $20(61)$ & \\
\hline \multirow[t]{2}{*}{ Footbath use } & No & $29(88)$ & 0.187 \\
\hline & Yes & $4(12)$ & \\
\hline \multirow[t]{2}{*}{ TMR } & No & $16(48)$ & 0.031 \\
\hline & Yes & $17(52)$ & \\
\hline \multirow[t]{2}{*}{ Difficulty getting trimmer } & No & $20(63)$ & 0.133 \\
\hline & Yes & $12(38)$ & \\
\hline \multirow[t]{2}{*}{ Difficulty identifying lameness } & No & $22(67)$ & 0.085 \\
\hline & Yes & $11(33)$ & \\
\hline
\end{tabular}

${ }^{1}$ Does not always equal 33 due to missing data.

//doi.org/10.3168/jds.2018-15349). Of the 1,488 cows evaluated using SLS, $1,012(68 \%)$ had no behavioral changes, whereas $230(15 \%), 216(15 \%), 28(2 \%)$, and 2 $(<1 \%)$ had 1 to 4 behavioral changes, respectively. Of all cows evaluated, $22 \%$ were bearing weight unevenly, $14 \%$ were resting 1 foot, $9 \%$ were repeatedly shifting weight, and $6 \%$ were standing on the edge of the stall.
The prevalence of lameness for freestall-housed cows was $20.7 \%$ (95\% CI: 17.7-24.1). At the herd level, the prevalence of lameness in freestalls ranged from 0 to $52.3 \%$ (Supplemental Figure S2; https://doi.org/10 $.3168 /$ jds.2018-15349). Lameness scores were recorded dichotomously as $<3 / 5$ or $\geq 3 / 5$, so no comments can be made on the distribution of severity in lameness.

Table 3. Distribution of cow-level variables measured that were unconditionally associated with lameness $(P$ $\leq 0.2$ ) in 1,503 cows from 33 tiestall farms in Maritime Provinces of Canada

\begin{tabular}{|c|c|c|c|}
\hline Variable & Category & Cows, no. ${ }^{1}(\%)$ & $P$-value \\
\hline \multirow[t]{4}{*}{ Lactation } & 1 & $465(34)$ & $<0.001$ \\
\hline & 2 & $358(26)$ & \\
\hline & 3 & $227(17)$ & \\
\hline & $4+$ & $312(23)$ & \\
\hline \multirow[t]{4}{*}{ BCS } & $\leq 2.5$ & $302(20)$ & $<0.001$ \\
\hline & 2.75 & $581(39)$ & \\
\hline & 3 & $350(23)$ & \\
\hline & $\geq 3.25$ & $267(18)$ & \\
\hline \multirow[t]{2}{*}{ Leg cleanliness } & $\overline{\text { Clean }}$ & $1,457(97)$ & 0.075 \\
\hline & Dirty & $43(3)$ & \\
\hline \multirow[t]{4}{*}{ Stall length $(\mathrm{cm})$} & $<165$ & $190(13)$ & 0.107 \\
\hline & $165-174$ & $614(41)$ & \\
\hline & $175-184$ & $497(33)$ & \\
\hline & $\geq 185$ & $198(13)$ & \\
\hline \multirow[t]{4}{*}{ Stall width $(\mathrm{cm})$} & $<120$ & $250(17)$ & 0.055 \\
\hline & $120-124$ & $444(30)$ & \\
\hline & $125-134$ & $289(19)$ & \\
\hline & $\geq 135$ & $515(34)$ & \\
\hline \multirow[t]{5}{*}{ Tie rail to rear curb distance $(\mathrm{cm})$} & $\overline{<} 180$ & $199(13)$ & 0.047 \\
\hline & 180-189 & $340(23)$ & \\
\hline & 190-199 & $543(36)$ & \\
\hline & 200-209 & $250(17)$ & \\
\hline & $\geq 210$ & $171(11)$ & \\
\hline Daily milk production (kg/cow) & & 1,347 & 0.001 \\
\hline Cow width $(\mathrm{cm})$ & & 1,498 & $<0.001$ \\
\hline
\end{tabular}

${ }^{1}$ Does not always equal 1,503 because of missing data. 
Table 4. Distribution of herd-level variables that were unconditionally associated with lameness $(P \leq 0.2)$ from 40 freestall herds in the Maritime Provinces of Canada

\begin{tabular}{|c|c|c|c|}
\hline Variable & Category & $\begin{array}{l}\text { Herds or pens, } \\
\text { no. }^{1}(\%)\end{array}$ & $P$-value \\
\hline Stall base & $\begin{array}{l}\text { Mattress } \\
\text { Rubber mat } \\
\text { Soil }\end{array}$ & $\begin{aligned} 23 & (57) \\
5 & (13) \\
12 & (30)\end{aligned}$ & 0.020 \\
\hline Dry cow housing & $\begin{array}{l}\text { Pack bedding } \\
\text { Other }\end{array}$ & $\begin{array}{l}18(45) \\
22(55)\end{array}$ & 0.023 \\
\hline Time away from pen daily & $\begin{array}{l}\text { AMS } \\
<3 \mathrm{~h} \\
\geq 3 \mathrm{~h}\end{array}$ & $\begin{array}{r}5(12) \\
13(33) \\
22(55)\end{array}$ & $<0.001$ \\
\hline Holding area floor & $\begin{array}{l}\text { Concrete } \\
\text { Rubber }\end{array}$ & $\begin{array}{r}31(78) \\
9(22)\end{array}$ & 0.020 \\
\hline Treatment time for lame cows & $\begin{array}{l}\text { Immediately } \\
\text { Delayed }\end{array}$ & $\begin{array}{l}28(70) \\
12(30)\end{array}$ & 0.125 \\
\hline Expense prevents immediate treatment & $\begin{array}{l}\text { Yes } \\
\text { No }\end{array}$ & $\begin{array}{l}10(26) \\
29(74)\end{array}$ & 0.032 \\
\hline Lack of time prevents immediate treatment & $\begin{array}{l}\text { Yes } \\
\text { No }\end{array}$ & $\begin{array}{l}19(47) \\
21(53)\end{array}$ & 0.001 \\
\hline Adequate lunge space & $\begin{array}{l}\text { Yes } \\
\text { No }\end{array}$ & $\begin{array}{l}24(60) \\
16(40)\end{array}$ & 0.128 \\
\hline Herd size & $\begin{array}{l}<50 \\
50-74 \\
75-94 \\
\geq 95\end{array}$ & $\begin{array}{r}15(37) \\
13(33) \\
5(12) \\
7(18)\end{array}$ & 0.036 \\
\hline Neck rail to curb distance $(\mathrm{cm})$ & $\begin{array}{l}<165 \\
165-174 \\
\geq 175\end{array}$ & $\begin{array}{l}13(32) \\
16(40) \\
11(28)\end{array}$ & 0.200 \\
\hline Stocking density & $\begin{array}{l}<1 \mathrm{cow} / \mathrm{stall} \\
\geq 1 \mathrm{cow} / \mathrm{stall}\end{array}$ & $\begin{array}{l}26(65) \\
14(35)\end{array}$ & 0.134 \\
\hline Average brisket board height $(\mathrm{cm})$ & & 40 & 0.158 \\
\hline
\end{tabular}

\section{Risk Factors Associated with Lameness}

No variables were found to be highly correlated $(0.7)$ for either facility type; therefore, all variables that were significant after univariable analysis were used for the multivariable analysis. The results indicate that, in tiestall facilities, odds of lameness were 2.66 times higher when the bedding was wet than when the bedding was dry. The remaining results and risk factors significantly associated with lameness for tiestall facilities in this study are presented in Table 6 . The variability between herds that was unexplained by the final model was $9 \%$.

Results from the analysis for freestall facilities indicate that cows with a holding time of $\geq 3 \mathrm{~h} / \mathrm{d}$ and cows in AMS herds had 2.11 and 1.67 higher odds of being lame, respectively, compared with cows that were in the holding area for $<3 \mathrm{~h} / \mathrm{d}$. The results from the final multivariable model for freestalls and the risk factors

Table 5. Distribution of cow-level variables that were unconditionally associated with lameness $(P \leq 0.2)$ measured in 2,758 cows from 40 freestall herds in the Maritime Provinces of Canada

\begin{tabular}{llrr}
\hline Variable & Category & Cows, no. ${ }^{1}(\%)$ & $P$-value \\
\hline Parity & 1 & $1,011(37)$ & $<0.001$ \\
& 2 & $791(29)$ & \\
BCS & 3 & $453(16)$ & \\
& $\geq 4$ & $502(18)$ & $<0.001$ \\
& $\leq 2.5$ & $517(19)$ & \\
Leg cleanliness & 2.75 & $859(31)$ & 0.061 \\
DIM & 3.25 & $805(29)$ & $<0.001$ \\
Daily milk production $(\mathrm{kg} / \mathrm{d})$ & Clean & $2,512(91)$ & 0.011 \\
\hline
\end{tabular}

${ }^{1}$ Does not always equal 2,758 due to missing data. 
Table 6. Cow- and herd-level factors significantly associated with lameness after final logistic regression model in 33 tiestall herds in the Maritime Provinces ( $\mathrm{n}=1,346$ cows)

\begin{tabular}{|c|c|c|c|c|c|c|}
\hline Variable & Category & Coefficient & $\mathrm{SE}$ & $\begin{array}{l}\text { Odds } \\
\text { ratio }^{1}\end{array}$ & $\begin{array}{c}95 \% \text { CI } \\
\text { odds ratio }\end{array}$ & $\begin{array}{l}\text { Overall } \\
P \text {-value }\end{array}$ \\
\hline Bedding dryness & Dry & Referent & & & & \\
\hline Dry cow/heifer housing system & Pack bedding & -0.69 & 0.28 & 0.50 & $0.29-0.87$ & 0.013 \\
\hline \multirow[t]{2}{*}{ Parity } & 1 & Referent & & & & $<0.001$ \\
\hline & 2 & 0.58 & 0.28 & 1.79 & $1.03-3.11$ & \\
\hline \multirow[t]{4}{*}{ BCS } & $\overline{\leq} 2.5$ & Referent & & & & $<0.001$ \\
\hline & $\overline{2} .75$ & -0.46 & 0.22 & 0.63 & $0.41-0.97$ & \\
\hline & 3 & -1.01 & 0.27 & 0.36 & $0.21-0.62$ & \\
\hline & $\geq 3.25$ & -1.32 & 0.32 & 0.27 & $0.14-0.50$ & \\
\hline Cow width $(\mathrm{cm})$ & & 0.09 & 0.03 & 1.10 & $1.04-1.15$ & 0.001 \\
\hline Milk production (10 kg increase/cow per day) & & -0.21 & 0.11 & 0.81 & $0.66-0.99$ & 0.045 \\
\hline Constant & & -8.77 & 1.74 & & & \\
\hline
\end{tabular}

${ }^{1}$ All results are presented as cluster-specific estimates.

significantly associated with lameness are presented in Table 7 . The variability between herds that was unexplained by this model was $3 \%$.

\section{DISCUSSION}

Eighty herds (13.6\%) out of a possible 588 farms available for participation from the region were chosen for this study. Within the Maritime Provinces, approximately $50 \%$ are tiestall herds and $50 \%$ are freestall herds, of which $5 \%$ are AMS herds, as reported by CDIC (2016). The average size for tiestall herds in this region is 60 cows, and the average size for freestall herds is 120 cows, with an average production of $10,187 \mathrm{~kg} / \mathrm{cow}$ per year (CDIC, 2016). The study population consisted of a similar demographic, with $43 \%$ tiestalls and $57 \%$

Table 7. Cow- and herd-level factors significantly associated with lameness in 39 freestall herds $(\mathrm{n}=2,670$ cows $)$

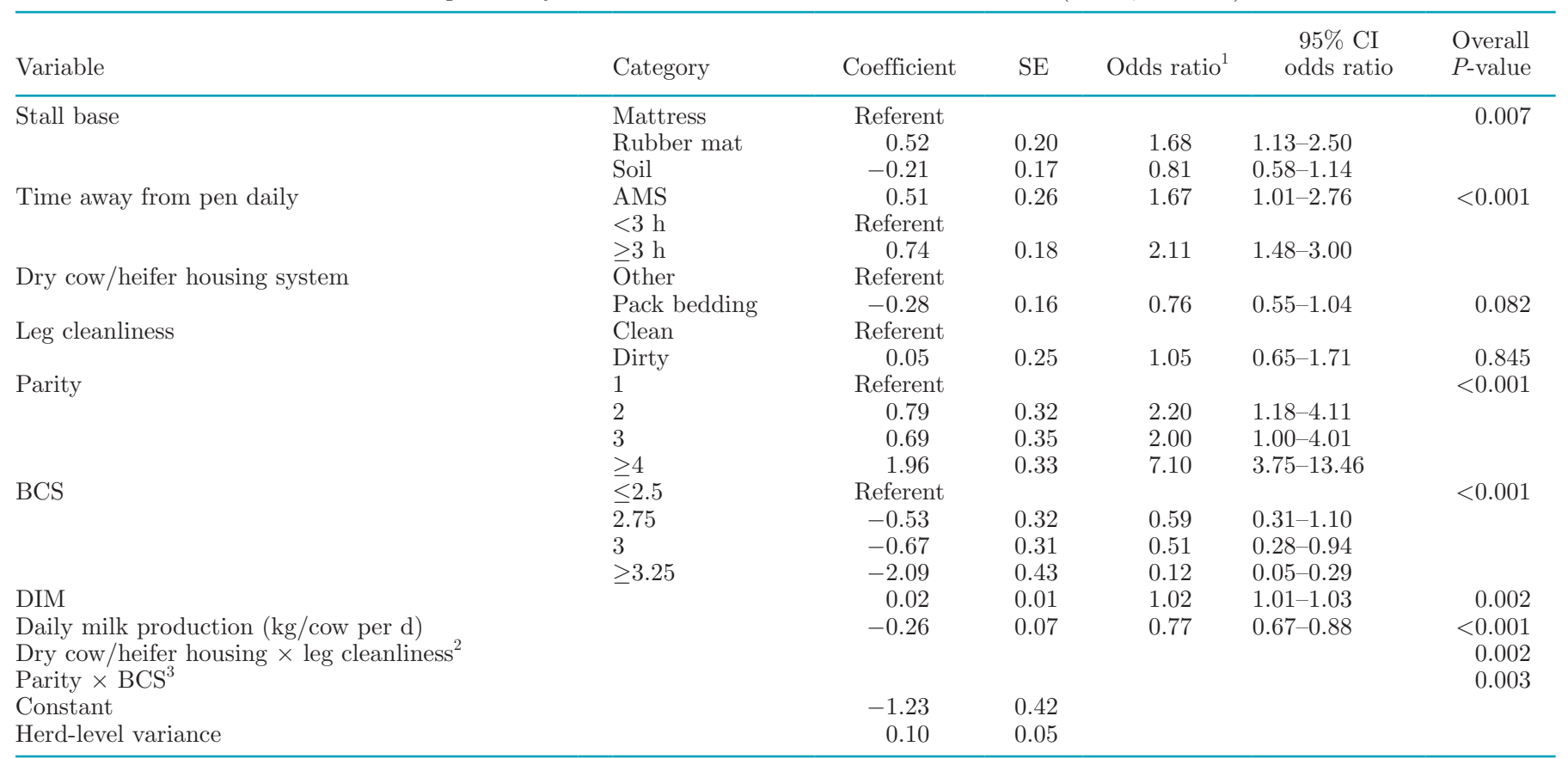

\footnotetext{
${ }^{1}$ All results are presented as cluster-specific estimates.

${ }^{2}$ Results are presented in Figure 4.

${ }^{3}$ Results are presented in Figure 5.
} 
freestalls of similar average size and production levels, and therefore was a good representation of the farm demographics in the Maritime region.

In this study, we found that the prevalence of lameness in freestall herds was $21 \%$, which is similar to levels reported in a recent Canadian study of freestall herds in Ontario, Alberta, and Quebec (Solano et al., 2015). In this study, the prevalence of lameness in tiestalls was lower than that in freestalls, at $15 \%$, and lower than the most recent Canadian reports of $25 \%$ (Nash et al., 2016; Bouffard et al., 2017). The majority of tiestall herds that were included in the current study had access to pasture during the summer months, whereas the previous study included herds that did not graze their animals. Grazing has been found to decrease the risk of lameness (Onyiro et al., 2008); therefore, the lower prevalence in this study could be because cows were not kept housed year round. Lameness was determined using 2 different methods in this study, therefore making it difficult to compare the prevalence of lameness in freestall and tiestall herds. It is possible that the prevalence of lameness in tiestall herds was underestimated because the method of assessment evaluated the hind limbs only, whereas locomotion scoring in freestalls captured both hind-limb and fore-limb lameness. It is also possible that SLS was unable to classify all lame cows correctly, as it was found that $24 \%$ false negatives were identified when comparing SLS with locomotion scoring (Gibbons et al., 2014). That study concluded that this method is useful for estimating the prevalence of lameness in a herd but is not as accurate for determining individual cow lameness. For these reasons, we should not make comparisons in the prevalence between tiestalls and freestalls in this study.

Because cows in freestall facilities were assessed anywhere throughout the pen, the surface on which cows were walking could differ between and within herds. Gait scores have been found to improve when cows are walking on higher friction surfaces, such as rubber flooring, compared with concrete (Telezhenko and Bergsten, 2005; Flower et al., 2007). It is possible that cows in our study that were assessed on rubber flooring would have different scores if they were assessed on concrete. In this study, there were a low number of herds with rubber flooring $(7 \%)$, and no relationship between flooring type and lameness was found.

Enrollment in the study was voluntary; therefore, the potential for selection bias exists because herds with higher levels of lameness and poor management are more likely to decline participation. Even though the study population was not randomly selected from the target population, we still found wide variation between herds for the prevalence of lameness. It is possible that the prevalence of lameness reported in this study could be under- or overestimated compared with if a random selection of herds was completed.

Although the methods of assessment were different and management differed between facility types, similar risk factors were associated with lameness in tiestalls and freestalls. In both facility types, we found that the majority of the variation explained by the logistic regression models was at the cow level (Figures 2 and 3 ), which is in agreement with previous studies (Solano et al., 2015). Although the majority of the risk factors were at the cow level, a few herd-level factors may have had a direct or indirect causal role in lameness. Implementing changes in these areas could help producers reduce the prevalence of lameness in their herds. In freestall facilities, the amount of time that cows spend away from the pen, specifically during milking, affects the time budget of the animal and their hoof health (Cook et al., 2004; Espejo and Endres, 2007). We found that cows that spent $\geq 3 \mathrm{~h}$ away from their pen were 2.11 times more likely to be lame than those that spent $<3 \mathrm{~h}$ away from their pen. Although cows in AMS do not spend much time away from their pen, we found that they were 1.67 times more likely to be lame than those in traditional parlor systems with a waiting time of $<3 \mathrm{~h}$. These results could be a reflection of facility design and management factors that were not found to be significantly associated with lameness in our study but have been previously associated with lameness, specifically in AMS herds. These factors include the frequency of alleys being scraped, stocking density, stall dimensions, and width of the feed alleys (King et al., 2016; Westin et al., 2016). There were only 5 AMS herds in the current study; it would have been beneficial to have more AMS herds to compare with traditional parlor systems.

Another herd-level risk factor in freestalls was the type of stall surface that was used. In agreement with other studies, we found that cows housed on soil-based stalls were less likely to be lame than those housed on mattresses (Chapinal et al., 2013; Solano et al., 2015; Cook et al., 2016). This finding could be a reflection of how much bedding was provided, as previous studies have found that providing deep bedding was associated with a lower risk of lameness (Chapinal et al., 2013; Solano et al., 2015). Although the depth of bedding was not significantly associated with lameness in the current study, all 11 herds with soil-based stalls had deep bedding, whereas only 10 of the 24 herds (42\%) with mattresses had deep bedding. Although lying behavior was not measured in our study, the difference found between soil-based stalls and mattresses in the current study could also be a reflection of this behavior. Cook and Nordlund (2009) reported that when lame cows were housed on sand-based stalls, the softer, deeper 
bedding allowed for traction and ease of rising and lowering in the stall. For this reason, lame cows spent more time lying in the stalls, providing them more time to recover compared with lame cows on mattresses, who spent more time standing idle in the stall.

In tiestall facilities, we found that cows housed on wet bedding had 2.5 times higher odds of showing behavioral changes of lameness than those housed on dry bedding. Experimental studies have shown that exposure of bovine hooves to urine and fecal contamination causes the hoof to swell and soften (Gregory, 2004; Gregory et al., 2006). Although the relationship between claw hardness and hoof lesions is not easily defined, there is some evidence to support that cows with softer claws are at an increased risk of developing more severe hoof lesions (Borderas et al., 2004), which may result in increased gait scores (Flower and Weary, 2006). It is important to keep the environment that cattle are housed in clean and dry to reduce the prevalence of lameness in dairy cattle.

Another aspect to consider is where the dry cows and heifers are housed before entering the lactating herd. In this study, we found that when cows were housed in deep-bedded straw packs during this stage of their lactation cycles, odds of lameness were lower compared with when they were housed in tiestalls or freestalls during the dry period regardless of the lactating cow facility type. Placing cattle on straw packs has been shown to help heal hoof lesions, such as sole ulcers and white line disease (Livesey et al., 1998); therefore, housing animals in this type of facility during the dry period could aid in treating lame cows. Housing cattle on straw packs has 2 main benefits for hoof health: (1) it decreases the mechanical stress placed on the sole and (2) cattle lie down for longer compared with freestall-housed cattle (Webster, 2002). Providing pack bedding during the dry period, or even during lactation, would likely be beneficial for the older animals in the herd by improving their hoof health and ultimately the longevity of the herd. In freestall facilities, an interaction with dry cow housing and leg cleanliness was also identified (Figure 4). These results show that, when cows are housed in tiestalls or freestalls during the dry period, the cleanliness of the leg does not significantly change the odds of being lame. When cows are housed in pack-bedded facilities, the odds of becoming lame were significantly lower when the hind limb of the cow was considered dirty. Studies on cleanliness in different housing systems have shown that cows housed on straw-bedded packs are dirtier than those in cubicle housing (Fregonesi and Leaver, 2001). Perhaps the dry cows that had dirty hind limbs spent more time lying down, decreasing their risk of being lame in their next lactation. Further information would be required on

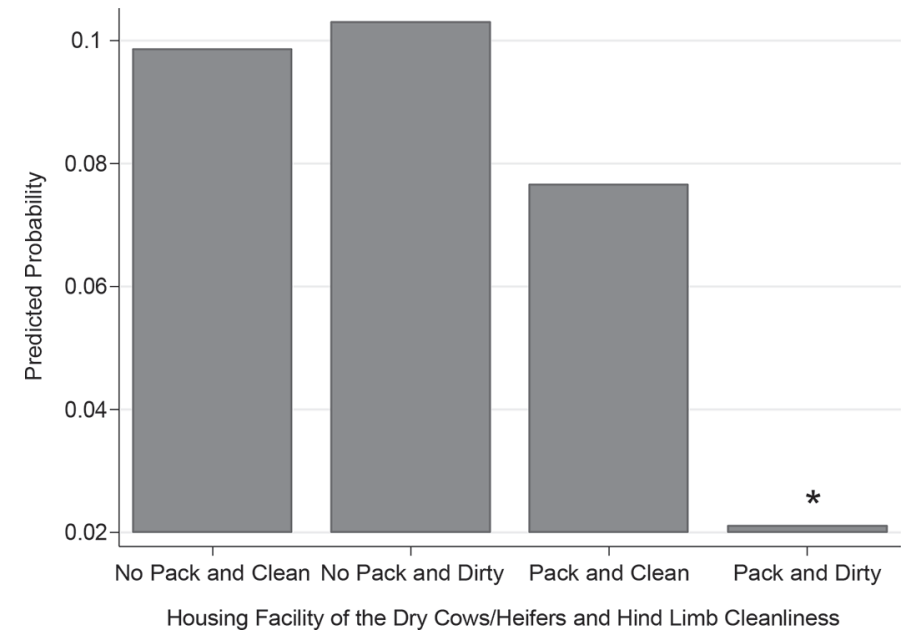

Figure 4. Plot of the predicted probability of lameness in freestall herds for the interaction between dry cow and heifer housing system and hind limb cleanliness, with all other variables being constant. Asterisk $(*)$ denotes significant difference from the other groups.

the lying time and cleanliness during the dry period to make further conclusions.

The majority of factors found to be associated with lameness in this study were cow-level factors, such as BCS, DIM, parity, and production. We found that cows with lower BCS $(\leq 2.5)$ were at a higher risk of lameness than those that were in better condition (Randall et al., 2015; Solano et al., 2015). The digital cushion that is located in the bovine hoof, to help absorb the forces applied to the foot during locomotion, comprises adipose tissue. As we would expect, when the cow is underconditioned, the thickness of the digital cushion decreases, therefore not providing as much support to the hoof and increasing the risk of lameness (Bicalho et al., 2009). It has been reported that cows are at a higher risk of developing a noninfectious hoof lesion (e.g., sole ulcer or white line disease) if they were previously classified as underconditioned (BCS $<2.5$; Green et al., 2014). In freestall facilities, we found that the risk of lameness increased with increasing parity (Vanegas et al., 2006; Randall et al., 2015; Solano et al., 2015) and decreasing BCS. The relationship with lameness for these 2 variables was found to be dependent on one another. Figure 5 shows that first-lactation animals that were well conditioned (BCS $\geq 3.25$ ) had significantly lower odds of lameness compared with first-lactation animals that were less conditioned $(\mathrm{BCS} \leq 3)$. For animals in third lactation, the odds of lameness did not differ significantly based on BCS. Cows in fourth or greater lactation that were underconditioned (BCS $\leq 2.5$ ) had the highest odds of lameness compared with all other groups. Cows that have been lame previously are at a higher risk of becoming lame again (Green et 


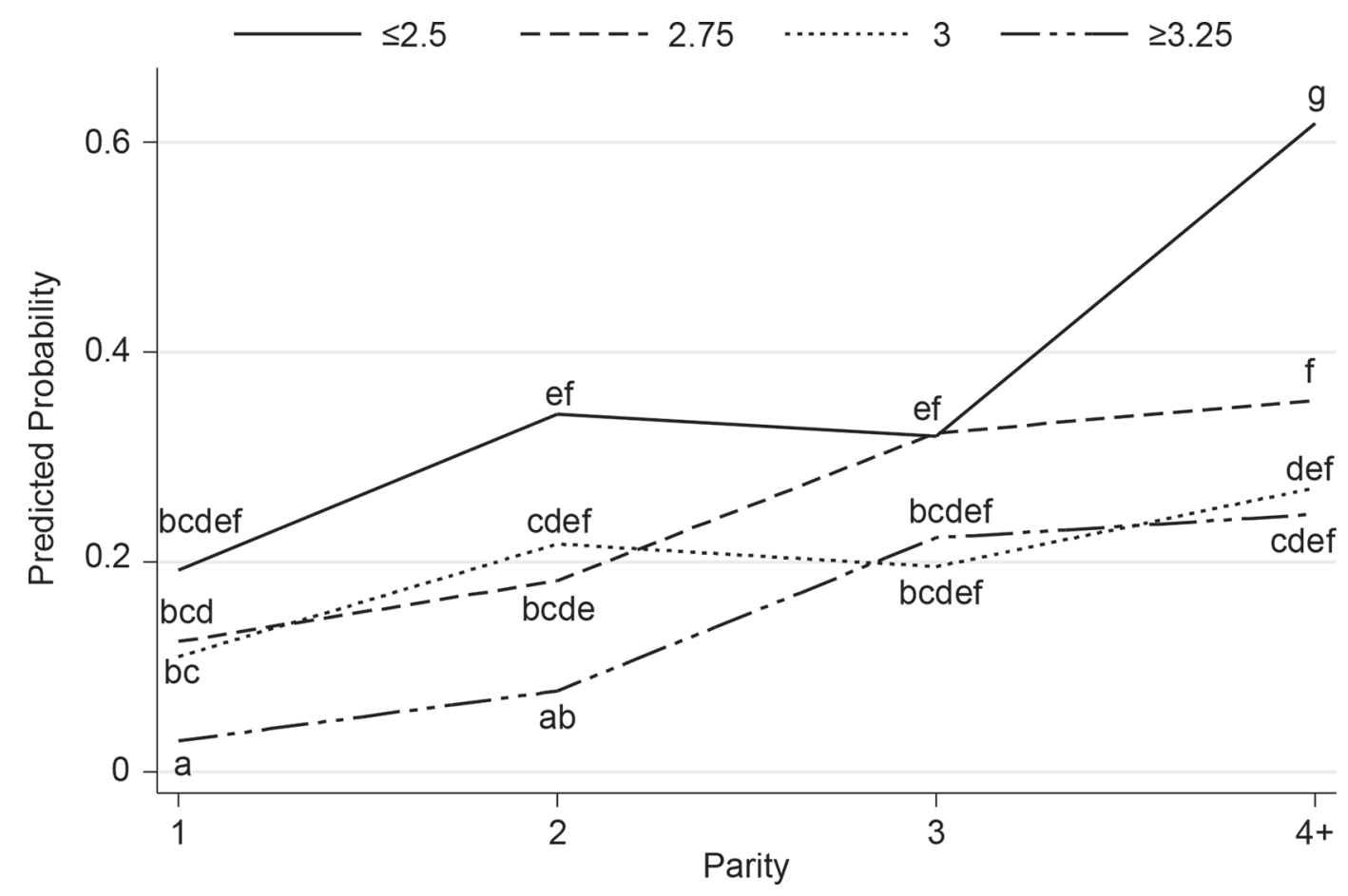

Figure 5. Plot of the predicted probability of lameness in freestall herds for the interaction between parity and BCS, with all other variables being constant. Letters $(\mathrm{a}-\mathrm{g})$ above or below the closest point on the graph correspond to grouping after Bonferroni adjustments, where differences in letters indicate significant differences between groups.

al., 2014); therefore, the older animals in this study could have been lame previously and were unable to regain body condition, increasing their risk of lameness further. Lame cows may spend more time lying down during the day (Solano et al., 2016) because it may be too painful to stand or remain standing (Chapinal et al., 2009; Ito et al., 2010). If this is the case, it may be too painful for lame cows to stand at the feed bunk and eat as long as the other cows in the herd, making them more likely to lose body condition. The results show that it is important for producers to correct low body condition, especially for older cows, to help reduce the prevalence of lameness.

In freestall facilities, the risk of lameness increased with increasing DIM (Onyiro et al., 2008; Solano et al., 2015). This could be related to the thickness of the digital cushion, as it is thickest at the beginning of lactation and gradually decreases to the thinnest at 4 mo postcalving, before beginning to increase in thickness again (Bicalho et al., 2009). It could also be that the cows were previously lame in the lactation and were at a higher risk of becoming lame again (Green et al., 2014). We found that risk of lameness decreased as daily milk production increased, in agreement with other studies (Onyiro et al., 2008; Green et al., 2014; Solano et al., 2015). It is believed that higher producing cows are at a higher risk of lameness (Green et al.,
2002; Onyiro et al., 2008) but that their production levels decrease before signs of lameness become evident (Reader et al., 2011; Green et al., 2014). Because we measured lameness and milk production at only one point in time, it is possible that our results could be a reflection of this. The cows that were lame in our study could have had higher production earlier in their lactation but decreased production before and during the time they were considered to be lame. Without followup, it is unknown whether those higher producing cows in our study became lame later in their lactation. If producers are aware of this potential relationship, they could monitor their higher producing cows and use any reduction in production as an early indicator of lameness.

\section{CONCLUSIONS}

This study found that the prevalence of lameness within herds can be high in the Maritime dairy industry but overall is comparable with that in other areas of Canada. Some herds in the study were able to achieve low levels of lameness, showing that this is an achievable goal for the regional dairy industry. Although the majority of risk factors found in this study were at the cow level, some areas of management and facility design were identified in which producers could implement 
changes and lower the risk of lameness. This could be achieved by ensuring that cattle are provided with dry bedding and making sure that the time away from the pen is $<3 \mathrm{~h} / \mathrm{d}$. Dry cows and heifers could be housed in pack-bedded systems to improve hoof health before entering the lactating herd. A higher risk of lameness was identified for older animals, those in a later stage of lactation, those that are underconditioned, and those with lower milk production. Making producers aware of these risk factors could help them manage their herds better and reduce the prevalence of lameness.

\section{ACKNOWLEDGMENTS}

This research was supported mainly by Agriculture and Agri-Food Canada (Ottawa, ON, Canada) and by additional contributions from Dairy Farmers of Canada (Ottawa, ON, Canada), the Canadian Dairy Network (Guelph, ON, Canada), the Canadian Dairy Commission under the Agri-Science Clusters Initiative (Ottawa, ON, Canada), and the Sir James Dunn Animal Welfare Centre (Charlottetown, PE, Canada). Per the research agreement, aside from providing financial support, the funders had no role in the design and conduct of the studies, data collection and analysis, or interpretation of the data. The researchers maintain independence in conducting their studies, own their data, and report the outcomes regardless of the results. The decision to publish the findings rests solely with the researchers. We thank the technicians and students from Atlantic Veterinary College (University of Prince Edward Island, Charlottetown, PE, Canada) for their work in completing the on-farm assessments.

\section{REFERENCES}

Bicalho, R. C., V. S. Machado, and L. S. Caixeta. 2009. Lameness in dairy cattle: A debilitating disease or a disease of debilitated cattle? A cross-sectional study of lameness prevalence and thickness of the digital cushion. J. Dairy Sci. 92:3175-3184.

Bicalho, R. C., C. F. Vokey, H. N. Erb, and C. L. Guard. 2007. Visual locomotion scoring in the first seventy days in milk; Impact on pregnancy and survival. J. Dairy Sci. 90:4586-4591.

Borderas, T. F., B. Pawluczuk, A. M. de Passillé, and J. Rushen. 2004. Claw hardness of dairy cows: Relationship to water content and claw lesions. J. Dairy Sci. 87:2085-2093.

Bouffard, V., A. M. de Passillé, J. Rushen, E. Vasseur, C. G. R. Nash, D. B. Haley, and D. Pellerin. 2017. Effect of following recommendations for tiestall configuration on neck and leg lesions, lameness, cleanliness, and lying time in dairy cows. J. Dairy Sci. 100:29352943.

CDIC (Canadian Dairy Information Centre). 2016. Dairy facts and figures. Accessed Jan. 5, 2018. http://www.dairyinfo.gc.ca/index _e.php?s1=dff-fcil.

Cha, E., J. A. Hertl, D. Bar, and Y. T. Gröhn. 2010. The cost of different types of lameness in dairy cows calculated by dynamic programming. Prev. Vet. Med. 97:1-8.

Chapinal, N., A. K. Barrientos, M. A. G. von Keyserlink, E. Galo, and D. M. Weary. 2013. Herd-level risk factors for lameness in freestall farms in the northeastern United States and California. J. Dairy Sci. 96:318-328.

Chapinal, N., A. M. de Passillé, D. M. Weary, M. A. G. von Keyserlingk, and J. Rushen. 2009. Using gait score, walking speed, and lying behavior to detect hoof lesions in dairy cows. J. Dairy Sci. 92:4365-4374.

Cook, N. B., T. B. Bennett, and K. V. Nordlund. 2004. Effect of free stall surface on daily activity patterns in dairy cows with relevance to lameness prevalence. J. Dairy Sci. 87:2912-2922.

Cook, N. B., J. P. Hess, M. R. Foy, T. B. Bennett, and R. L. Brotzman. 2016. Management characteristics, lameness, and body injuries of dairy cattle housed in high-performance dairy herds in Wisconsin. J. Dairy Sci. 99:5879-5891.

Cook, N. B., and K. V. Nordlund. 2009. The influence of the environment on dairy cow behaviour, claw health and herd lameness dynamics. Vet. J. 179:360-369.

Cramer, G., K. D. Lissemore, C. L. Guard, K. E. Leslie, and D. F. Kelton. 2009. The association between foot lesions and culling risk in Ontario Holstein cows. J. Dairy Sci. 92:2572-2579.

Dohoo, I., W. Martin, and H. Stryhn. 2009. Veterinary Epidemiologic Research. 2nd ed. VER Inc., Charlottetown, PE, Canada.

Espejo, L. A., and M. I. Endres. 2007. Herd-level risk factors for lameness in high-producing Holstein cows housed in freestall barns. J. Dairy Sci. 90:306-314.

Flower, F. C., A. M. de Passillé, D. M. Weary, D. J. Sanderson, and J. Rushen. 2007. Softer, higher-friction flooring improves gait of cows with and without sole ulcers. J. Dairy Sci. 90:1235-1242.

Flower, F. C., and D. M. Weary. 2006. Effect of hoof pathologies on subjective assessments of dairy cow gait. J. Dairy Sci. 89:139-146.

Forsberg, A. M., G. Pettersson, T. Ljungberg, and K. SvennerstenSjaunja. 2008. A brief note about cow lying behavior-Do cows choose left and right lying side equally? Appl. Anim. Behav. Sci. 114:32-36.

Fregonesi, J. A., and J. D. Leaver. 2001. Behaviour, performance and health indicators of welfare for dairy cows housed in strawyard or cubicle systems. Livest. Prod. Sci. 68:205-216.

Garbarino, E. J., J. A. Hernandez, J. K. Shearer, C. A. Risco, and W. W. Thatcher. 2004. Effect of lameness on ovarian activity in postpartum Holstein cows. J. Dairy Sci. 87:4123-4131.

Gibbons, J., D. B. Haley, J. Higginson Cutler, C. Nash, J. Zaffino Heyerhoff, D. Pellerin, S. Adams, A. Fournier, A. M. de Passillé, J. Rushen, and E. Vasseur. 2014. Technical note: A comparison of 2 methods of assessing lameness prevalence in tiestall herds. J. Dairy Sci. 97:350-353.

Gibbons, J., E. Vasseur, J. Rushen, and A. M. de Passillé. 2012. A training programme to ensure high repeatability of injury scoring of dairy cows. Anim. Welf. 21:379-388.

Green, L. E., V. J. Hedges, Y. H. Schukken, R. W. Blowey, and A. J. Packington. 2002. The impact of clinical lameness on the milk yield of dairy cows. J. Dairy Sci. 85:2250-2256.

Green, L. E., J. N. Huxley, C. Banks, and M. J. Green. 2014. Temporal associations between low body condition, lameness and milk yield in a UK dairy herd. Prev. Vet. Med. 113:63-71.

Gregory, N. G. 2004. Swelling of cattle heel horn by urine. Aust. Vet. J. 82:161-163.

Gregory, N. G., L. Craggs, N. Hobson, and C. Krough. 2006. Softening of cattle hoof soles and swelling of heel horn by environmental agents. Food Chem. Toxicol. 44:1223-1227.

Ito, K., M. A. G. von Keyserlingk, S. J. LeBlanc, and D. M. Weary. 2010. Lying behaviour as an indicator of lameness in dairy cows. J. Dairy Sci. 93:3553-3560.

King, M. T. M., S. J. LeBlanc, E. A. Pajor, and T. J. DeVries. 2017. Cow-level associations of lameness, behaviour, and milk yield of cows in automated systems. J. Dairy Sci. 100:4818-4828.

King, M. T. M., E. A. Pajor, S. J. LeBlanc, and T. J. DeVries. 2016. Associations of herd-level housing, management, and lameness prevalence with productivity and cow behaviour in herds with automated milking systems. J. Dairy Sci. 99:9069-9079.

Leach, K. A., S. Dippel, J. Huber, S. March, C. Winckler, and H. R. Whay. 2009. Assessing lameness in cows kept in tie-stalls. J. Dairy Sci. 92:1567-1574. 
Livesey, C. T., T. Harrington, A. M. Johnston, S. A. May, and J. A. Metcalf. 1998. The effect of diet and housing on the development of sole haemorrhages, white line haemorrhages and heel erosions in Holstein heifers. Anim. Sci. 67:9-16.

Nash, C. G. R., D. F. Kelton, T. J. DeVries, E. Vasseur, J. Coe, J. C. Zaffino Heyerhoff, V. Bouffard, D. Pellerin, J. Rushen, A. M. de Passillé, and D. B. Haley. 2016. Prevalence of and risk factors for hock and knee injuries on dairy cows in tiestall housing in Canada. J. Dairy Sci. 99:6494-6506.

Onyiro, O. M., J. Offer, and S. Brotherstone. 2008. Risk factors and milk yield losses associated with lameness in Holstein-Friesian dairy cattle. Animal 2:1230-1237.

Palacio, S., L. Peignier, C. Pachoud, C. Nash, S. Adam, R. Bergeron, D. Pellerin, A. M. de Passillé, J. Rushen, D. Haley, T. J. DeVries, and E. Vasseur. 2017. Technical note: Assessing lameness in tiestalls using live stall lameness scoring. J. Dairy Sci. 100:6577-6582.

Randall, L. V., M. J. Green, M. G. G. Chagunda, C. Mason, S. C. Archer, L. E. Green, and J. N. Huxley. 2015. Low body condition predisposes cattle to lameness: An 8-year study of one dairy herd. J. Dairy Sci. 98:3766-3777.

Reader, J. D., M. J. Green, J. Kaler, S. A. Mason, and L. E. Green. 2011. Effect of mobility score on milk yield and activity in dairy cattle. J. Dairy Sci. 94:5045-5052.

Solano, L., H. W. Barkema, E. A. Pajor, S. Mason, S. J. LeBlanc, C. G. R. Nash, D. B. Haley, D. Pellerin, J. Rushen, A. M. de Passillé, E. Vassuer, and K. Orsel. 2016. Associations between lying behavior and lameness in Canadian Holstein-Friesian cows housed in freestall barns. J. Dairy Sci. 99:2086-2101.

Solano, L., H. W. Barkema, E. A. Pajor, S. Mason, S. J. LeBlanc, J. C. Zaffino Heyerhoff, C. G. Nash, D. B. Haley, E. Vasseur, D. Pellerin, J. Rushen, A. M. de Passillé, and K. Orsel. 2015. Prevalence of lameness and associated risk factors in Canadian Holstein-Friesian cows housed in freestall barns. J. Dairy Sci. 98:6978-6991.
Telezhenko, E., and C. Bergsten. 2005. Influence of floor type on the locomotion of dairy cows. Appl. Anim. Behav. Sci. 93:183-197.

Vanegas, J., M. Overton, S. L. Berry, and W. M. Sischo. 2006. Effect of rubber flooring on claw health in lactating dairy cows housed in free-stall barns. J. Dairy Sci. 89:4251-4258.

Vasseur, E., J. Gibbons, J. Rushen, and A. M. de Passillé. 2013. Development and implementation of a training program to ensure high repeatability of body condition scoring of dairy cows. J. Dairy Sci. 96:4725-4737.

Vasseur, E., J. Gibbons, J. Rushen, D. Pellerin, E. Pajor, D. Lefebvre, and A. M. de Passillé. 2015. An assessment tool to help producers improve cow comfort on their farms. J. Dairy Sci. 98:698-708.

von Keyserlingk, M. A. G., A. Barrientos, K. Ito, E. Galo, and D. M. Weary. 2012. Benchmarking cow comfort on North American freestall dairies: Lameness, leg injuries, lying time, facility design, and management for high-producing Holstein dairy cows. J. Dairy Sci. 95:7399-7408.

Webster, A. J. F. 2002. Effects of housing practices on the development of foot lesions in dairy heifers in early lactation. Vet. Rec. 151:9-12.

Westin, R., A. Vaughan, A. M. de Passillé, T. J. DeVries, E. A. Pajor, D. Pellerin, J. M. Siegford, A. Witaifi, E. Vasseur, and J. Rushen. 2016. Cow- and farm-level risk factors for lameness on dairy farms with automated milking systems. J. Dairy Sci. 99:3732-3743.

Whay, H. R., D. C. Main, L. E. Green, and A. J. Webster. 2003. Assessment of the welfare of dairy cattle using animal-based measurements: Direct observation and investigation of farm records. Vet. Rec. 153:197-202.

Zaffino Heyerhoff, J. C., S. J. LeBlanc, T. J. DeVries, C. G. R. Nash, J. Gibbons, K. Orsel, H. W. Barkema, L. Solano, J. Rushen, A. M. de Passillé, and D. B. Haley. 2014. Prevalence of and factors associated with hock, knee, and neck injuries on dairy cows in freestall housing in Canada. J. Dairy Sci. 97:173-184. 